\title{
Mitogen-Activated Protein Kinases and Hypoxic/Ischemic Nephropathy
}

\author{
Fengbao Luo Jian Shia Qianqian Shia Xianlin $\mathrm{Xu}^{\mathrm{a}}$ Ying Xia ${ }^{\mathrm{b}}$ Xiaozhou $\mathrm{He}^{\mathrm{a}}$ \\ aDepartment of Urology, The Third Affiliated Hospital of Soochow University, Changzhou, Jiangsu, China; \\ ${ }^{b}$ Department of Neurosurgery, The University of Texas McGovern Medical School, Houston, Texas, USA
}

\section{Key Words}

Hypoxia $\cdot$ Ischemia $・$ Nephropathy $・$ Renal protection $•$ Mitogen-activated protein kinases

\begin{abstract}
Tissue hypoxia/ischemia is a pathological feature of many human disorders including stroke, myocardial infarction, hypoxic/ischemic nephropathy, as well as cancer. In the kidney, the combination of limited oxygen supply to the tissues and high oxygen demand is considered the main reason for the susceptibility of the kidney to hypoxic/ischemic injury. In recent years, increasing evidence has indicated that a reduction in renal oxygen tension/blood supply plays an important role in acute kidney injury, chronic kidney disease, and renal tumorigenesis. However, the underlying signaling mechanisms, whereby hypoxia alters cellular behaviors, remain poorly understood. Mitogen-activated protein kinases (MAPKs) are key signaltransducing enzymes activated by a wide range of extracellular stimuli, including hypoxia/ ischemia. There are four major family members of MAPKs: the extracellular signal-regulated kinases-1 and -2 (ERK1/2), the c-Jun N-terminal kinases (JNK), p38 MAPKs, and extracellular signal-regulated kinase-5 (ERK5/BMK1). Recent studies, including ours, suggest that these MAPKs are differentially involved in renal responses to hypoxic/ischemic stress. This review will discuss their changes in hypoxic/ischemic pathophysiology with acute kidney injury, chronic kidney diseases and renal carcinoma.
\end{abstract}

\section{Introduction}

(C) 2016 The Author(s)

Published by S. Karger AG, Basel

Hypoxia/ischemia in the kidney is a widely encountered problem within vascular and urologic clinics because the kidney is sensitive to insufficient oxygen/blood delivery. This insufficiency leads to (or can be associated with) various pathological conditions, such as acute kidney injury, chronic kidney diseases, renal fibrosis, and renal cell carcinoma.

The kidneys are supplied with dense blood vessels, and high volumes of blood flow through them. Indeed, the blood flow to the kidney is second to the brain, and accounts for around $20 \%$ of cardiac output [1, 2]. Increasing renal blood flow increases glomerular

Ying Xia, M.D., Ph.D.

and Xiaozhou He, M.D.

KARGER
Department of Neurosurgery, The University of Texas McGovern Medical School, Houston, Texas 77030, (USA); and Department of Urology, The Third Affiliated Hospital of Soochow University, Changzhou, 213000, Jiangsu Province (China)

E-Mail Y55738088@gmail.com / Ying.Xia@uth.tmc.edu / czyyhxz@sina.com 
filtration rate and the filtered reabsorptive load. This increases oxygen demand due to a linear relationship between tubular transport of filtered sodium and oxygen consumption [3]. High metabolic activity, primarily due to the activity of the basolateral Na/K-ATPase, further increases oxygen demand. Consequently, the kidneys are very vulnerable to changes in oxygen supply. Hypoxia resulting from an imbalance in oxygen supply vs. demand has long been considered an important factor in the pathogenesis of kidney disease [4-7]. In acute and chronic kidney diseases, as well as in renal cancers, tissue hypoxia does not only cause energy deficiency, but also induces regulatory mechanisms that have a profound influence on signaling pathways [8].

The responses of renal cells to hypoxia encompass a series of signaling pathways that enables them to adapt to hypoxic conditions. Among the large array of signaling pathways activated in the kidney, mitogen-activated protein kinase (MAPK) pathways have been intensively studied recently [9-13]. MAPKs are a group of parallel cascades of serine/threonine kinases that regulate cell proliferation, differentiation, and survival. The understanding of molecular mechanisms underlying hypoxia-MAPK signaling regulation and their relevance to kidney diseases is crucial for preventing renal damage and promoting renal recovery after hypoxic/ischemic injury. In this review, we will focus on the roles of MAPKs in response to hypoxic/ischemic conditions in the kidney.

\section{Mitogen-activated protein kinases}

MAPKs regulate diverse biological functions including proliferation, development, differentiation, apoptosis, inflammation and fibrosis [14-16].The dysregulation of MAPKs arises in a variety of human diseases, including neurodegenerative and metabolic diseases, developmental disorders, as well as cancers [17-20]. There are four different MAPKs: extracellular signal-regulated kinase-1 and -2 (ERK1/2), c-Jun N-terminal kinase (JNK), p38 MAPK, and extracellular signal-regulated kinase-5 (ERK5/BMK1) [14, 21]. Each family of MAPKs is nonetheless activated through phosphorylation in a relatively specific fashion by a three-tiered cascade: MAPKKK, MAPKK and MAPK (Fig. 1). For example, ERK1/2 is activated by both MAPK/ERK kinase 1 and 2 (MEK1/2) whereas JNKs are activated primarily by MKK4 and MKK7 and p38 is activated by MKK3 and MKK6. Mammalian MAPK pathways can be

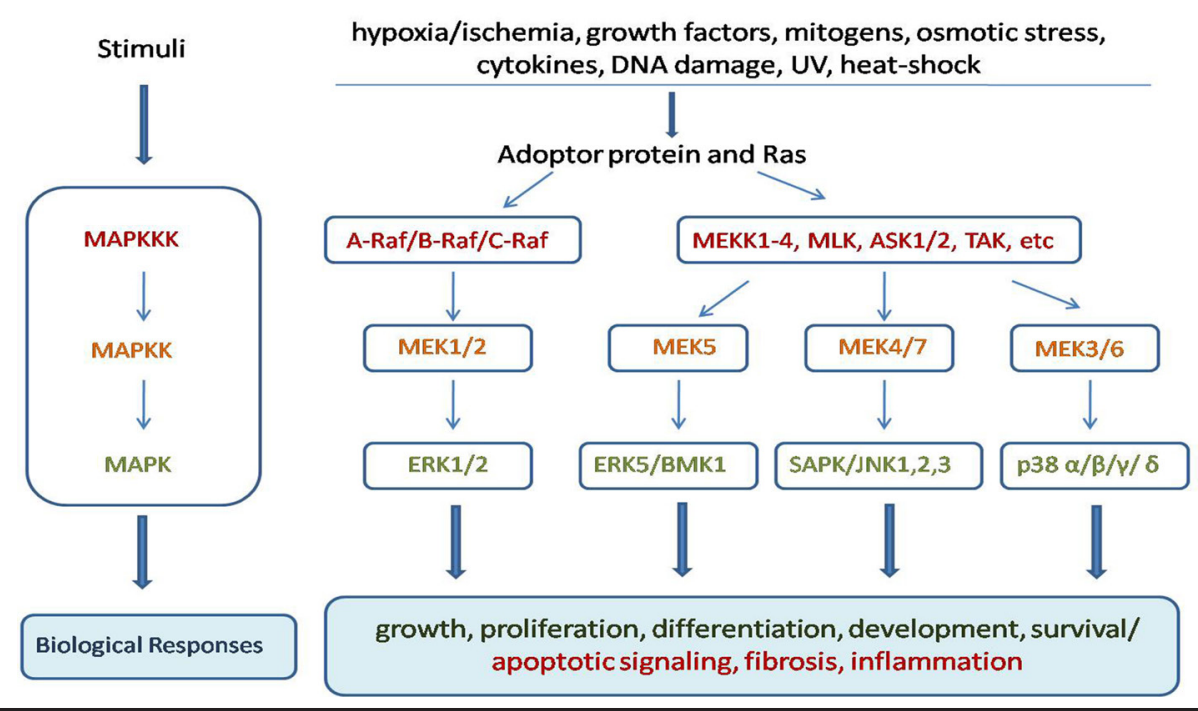

Fig. 1. The integral extracellular signal-regulated kinase/mitogen-activated protein kinase pathway. ERK: Extracellular signal-regulated kinase; SAPK/JNK, stress-activated protein kinase/c-Jun NH2-terminal kinase; MAPK: Mitogen-activated protein kinase; MEK, MAPK/ERK kinase; MEKK, MAPK/ERK kinase kinase; MKK, MAPK kinase; MKKK, MAPK kinase kinase. 
activated in response to a wide range of stimuli such as growth factors, cytokines, reactive oxygen species, UV, DNA damage, mitogens, heat shock and osmotic stress [14, 15, 22, 23]. Activated MAPKs can phosphorylate several intracellular targets including transcription factors, nuclear pore proteins, membrane transporters, cytoskeletal elements, and other protein kinases [24].

MAPKs are commonly expressed in many cell types in most tissues, and the kidney is no exception. In general, there are relatively low levels of active kinases in most "normal" tissues under physiological conditions, as kinase activation is largely restricted to tissue stress or injury. The activation of MAPKs is differentially involved in the progression of a plethora of human diseases, ranging from Parkinson's disease [25] to tumorigenesis [20]. For example, our previous studies showed increased levels of phosphorylated p38 with a decrease in phosphorylated ERK1/2 levels in cortical neurons after prolonged exposure to severe hypoxia. This was prevented by a hypoxic preconditioning treatment [26]. MAPKs are expressed differently at different stages of kidney development; while ERK1/2 and p38 are strongly expressed in a developing kidney, JNK is predominantly detected in an adult kidney [27]. However, all of their phosphorylation levels are altered under certain conditions. For instance, the phosphorylation of p38, ERK1/2 and JNK is significantly increased during hypoxia-reoxygenation in the human kidney cells [28]. Our recent studies found that ERK1/2 and p38 were dramatically activated in rat kidney epithelial cells (NRK-52E) under hypoxic conditions (Fig. 2, unpublished data), despite the fact that their activation is comparatively low under normal conditions. This finding suggests that renal cells are very different from neuronal cells in terms of MAPK responses to hypoxic stress because we previously found that ERK and p38 show opposite responses to prolonged hypoxia in neuronal cells [26].

It is widely believed that MAPKs are differentially involved in the genesis and/ or progression of many renal diseases, such as glomerulopathies, fibrosis, diabetic nephropathy, and renal carcinomas. MAPK pathways may regulate the pathogenesis of ischemia-reperfusion injury in a common pathway through activator protein 1 [29]. Also, a significant increase in cortical, and an even greater increase in glomerular ERK1/2 and JNK activity, was detected at 1, 3, and 7 days after induction of glomerulonephritis [30]. Gene expression patterns showed ERK1/2 activation in high-grade renal oncocytic carcinoma regions. ERK1/2's activation would further facilitate angiogenesis and invasiveness in those regions [31]. Moreover, recent in vivo and in vitro evidence suggests that the p38 pathway plays a very important role in the pathogenesis of diabetic nephropathy [32].

Despite extensive research in the past, the precise roles of different MAPKs in renal pathology, especially in hypoxic/ischemic nephropathy, are still not well understood, and there are also major controversies in the literature. For example, some studies showed that the activation of ERK1/2 signaling pathway in the human kidney with glomerulopathies correlated with cell proliferation, histologic lesions, renal fibrosis and dysfunction [33], while other work suggests that apoptosis in diabetic rat kidneys is likely related to a decrease in phosphorylated ERK1/2 levels and an increase in phosphorylated JNK levels [34]. A better understanding of renal MAPK function under hypoxic/ischemic conditions may therefore

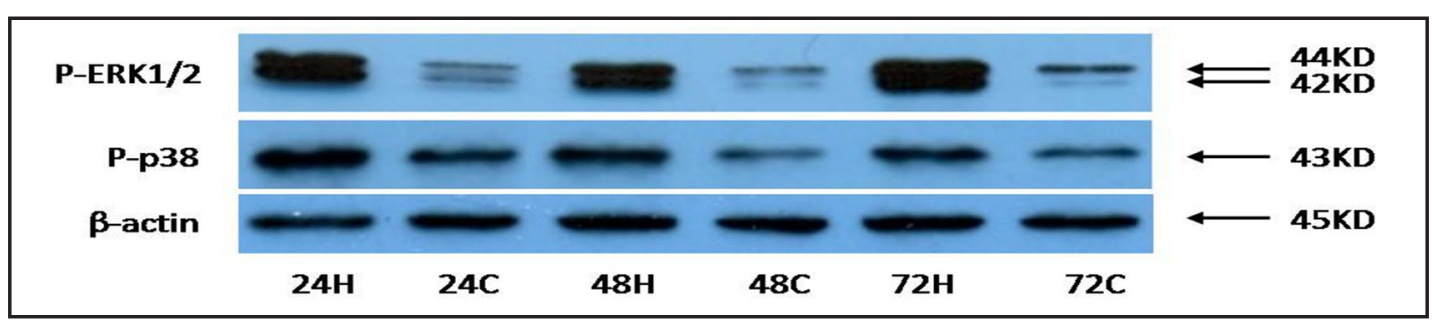

Fig. 2. ERK1/2 and p38 actiation by hypoxia in NRK-52E cells. NRK-52E cells were exposed to hypoxia at $1 \% \mathrm{O}_{2}$ for $24-72$ hours. $24 \mathrm{H}, 48 \mathrm{H}$ and $72 \mathrm{H}: 24,48$ and 72 hours in hypoxic control condition. 24C, 48C and 72C: 24, 48 and 72 hours in normoxic condition. Note that both phosphorylated ERK1/2 (P-ERK1/2) and p38 (P-p38) remarkably increased after hypoxic exposure. 
provide a novel insight into new therapies by targeting MAPK pathways for the prevention and treatment of hypoxic/ischemic diseases.

\section{Acute kidney injury}

Acute kidney injury (AKI) is the leading cause of nephropathy and is associated with high mortality, morbidity and health care expenditure. AKI may be caused by an array of insults, e.g. ischemia-reperfusion (I/R) injury, cardiovascular surgery, radio-contrast administration, and sepsis. In particular, ischemia/reperfusion injury is one of the most common causes of AKI and occurs in many clinical settings including kidney transplantation and cardiac bypass surgeries [35-38]. I/R during kidney transplantation can lead to graft rejection, delayed graft function, renal cell death, and chronic graft dysfunction [39]. Ischemic-induced renal tissue hypoxia along with the generation of reactive oxygen species during reperfusion are believed to contribute to tissue injury in the development of acute renal failure [40, 41]. Since I/R injury plays an essential role in hypoxic/ischemic nephropathy, many research efforts have been devoted to elucidating its mechanism $[42,43]$. However, the fundamental signaling pathways and the mechanisms of I/R injury are not yet fully understood.

The MAPKs participate in signal transduction pathways and the regulation of various cellular responses, such as cell proliferation, differentiation, and apoptosis [44, 45]. After hypoxic/ischemic injury, MAPK signaling pathways are activated in the kidney [46-49] as modulators of ischemia/reperfusion injury. In the past, many studies showed that p38 and JNK are pro-apoptotic, whereas ERKs are the modulators of cell survival under hypoxic/ ischemic conditions [46, 50-53]. After comprehensively reviewing the literature, however, we believe that the precise changes and roles of MAPK expression and phosphorylation are not that simple. In fact, there were many controversies even in recent studies, especially regarding their roles in protective or detrimental effects on the kidneys. Table 1 lists major results from recent studies on the role of MAPKs in renal I/R conditions.

\section{ERK1/2}

ERK1/2 activation can increase cell survival during oxidative injury; this can be prevented by ERK1/2 inhibition in the kidney [46]. Moreover, inhibition of monoamine oxidase after I/R insult potentiates ERK1/2 activation and increases proliferation, and it decreases necrosis of renal tubular cells [50]. The phosphorylation of ERK1/2, induced by heme oxygenase- 1 , enhanced tubular recovery and subsequently prevented further renal injury in mouse kidneys [54]. Stable overexpression of sec10 in Madin-Darby canine kidney cells significantly increased phosphorylated ERK1/2, which led to cell protection against I/R-induced oxidative injury by decreasing the degree of $\mathrm{H}_{2} \mathrm{O}_{2}$ injury and increasing the rate of epithelial barrier recovery following injury [55]. Furthermore, it was indicated that sec10 overexpression increased ERK1/2 phosphorylation and that recovery from oxidative injury in renal tubular was epidermal growth factor receptor, ERK1/2, and endocytosis dependent [56]. In addition, there is evidence showing that activated ERK1/2 plays a key role in the restoration of damaged tubular epithelial cells following I/R injury in mouse kidneys [57]. Ischemic postconditioning in NRK-52E cells is effective in mitigating renal cell apoptosis and it potentially be mediated via an ERK1/2 signal [58]. Erythropoietin pretreatment can also attenuate renal I/R injury by promoting activation of ERK1/2 signaling in rat kidneys, which causes the inhibition of apoptosis [59]. Etanercept, a TNF inhibitor, has the ability to strengthen renal protection from I/R injury by stimulating the activation of ERK1/2 and increasing the Bcl-2/Bax ratio [60]. These results strongly suggest that renal cell survival under oxidative injury is dependent on ERK1/2 activity.

However, ERK1/2 expression and phosphorylation along with its renoprotective roles are called into question by some other studies. For example, Ka et al. [61] showed that 4,5,6,7-tetrabromobenzotriazole, an ATP/GTP competitive inhibitor of casein kinase-2 (CK2, a protein kinase), significantly protects against renal I/R injury in mice and is associated with

\section{KARGER}




\begin{tabular}{|c|c|}
\hline Cellular Physiology & $\begin{array}{l}\text { Cell Physiol Biochem 2016;39:1051-1067 } \\
\text { DOI: 10.1159/000447812 } \\
\text { 2016 The Author(s). Published by S. Karger AG, Base }\end{array}$ \\
\hline a nisha & \begin{tabular}{l|l} 
DOI: 10.1159/000447812 \\
Published online: August 22, $2016 \begin{array}{l}\text { O 2016 The Author(s). Published by S. Karger AG, Basel } \\
\text { www.karger.com/cpp }\end{array}$
\end{tabular} \\
\hline
\end{tabular}

Table 1. Renal responses to MPAK changes in I/R conditions

\begin{tabular}{|c|c|c|c|}
\hline Stimuli/Conditions & $\begin{array}{l}\text { MAPK } \\
\text { Changes }\end{array}$ & Outcome & References \\
\hline $\begin{array}{l}\text { ischemic postconditioning in NRK- } 52 \mathrm{E} \text { cells or } \\
\text { erythropoietin or etanercept pretreatment in rat kidneys }\end{array}$ & $\mathrm{ERK} 1 / 2 \uparrow$ & cell survival & {$[58-60]$} \\
\hline hemin preconditioning in mouse I/R kidneys & $\mathrm{ERK} 1 / 2 \uparrow$ & $\begin{array}{l}\text { renal } \\
\text { protection }\end{array}$ & {$[54]$} \\
\hline ERK inhibition with PD-098059 in murine kidney cells & ERK1 $/ 2 \downarrow$ & $\begin{array}{l}\text { reduce cell } \\
\text { survival }\end{array}$ & {$[46]$} \\
\hline dexmedetomidine preconditioning in rat I/R kidneys & $\mathrm{p} 38 \uparrow$ & cell survival & [69] \\
\hline $\begin{array}{l}\text { lentivirus-mediated ERK5 overexpression with I/R in } \\
\text { human kidney cells }\end{array}$ & ERK5 $\uparrow$ & $\begin{array}{l}\text { renal } \\
\text { protection }\end{array}$ & {$[72]$} \\
\hline $\begin{array}{l}\text { BML-111 treatment in rat I/R kidneys; } \\
\text { SB203580 treatment in rat I/R kidneys }\end{array}$ & $\begin{array}{l}\text { p38 } \\
\text { p38 }\end{array}$ & $\begin{array}{l}\text { cell survival; } \\
\text { cell injury }\end{array}$ & {$[71]$} \\
\hline pretreatment with TBBt in mouse I/R kidneys & $\begin{array}{l}\text { ERK1/2, } \\
\text { p38 } \downarrow\end{array}$ & $\begin{array}{l}\text { renal } \\
\text { protection }\end{array}$ & {$[61]$} \\
\hline $\begin{array}{l}\text { low-molecular-weight fucoidan (LMWF) treatment in } \\
\text { mouse I/R kidneys }\end{array}$ & p38, JNK $\downarrow$ & $\begin{array}{l}\text { renal } \\
\text { protection }\end{array}$ & {$[28]$} \\
\hline glycyrrhizin treatment in mouse I/R kidneys & p38 $\downarrow$ & cell survival & {$[67]$} \\
\hline treatment with U0126 in rat kidney I/R models & 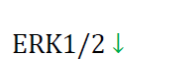 & $\begin{array}{l}\text { renal } \\
\text { protection }\end{array}$ & {$[62]$} \\
\hline $\begin{array}{l}\text { increased expression of ALDH-2 during I/R in rabbit } \\
\text { kidneys }\end{array}$ & $\begin{array}{l}\text { ERK1/2, p38, } \\
\text { JNK } \downarrow\end{array}$ & $\begin{array}{l}\text { renal } \\
\text { protection }\end{array}$ & {$[66]$} \\
\hline pargyline treatment in rat I/R kidneys & $\begin{array}{l}\mathrm{ERK} 1 / 2 \uparrow \\
\mathrm{JNK} \downarrow\end{array}$ & $\begin{array}{l}\text { renal } \\
\text { protection }\end{array}$ & {$[50]$} \\
\hline $\begin{array}{l}\text { preconditioning with low-dose cyclosporine A or FK506 in } \\
\text { rat I/R kidneys }\end{array}$ & $\begin{array}{l}\text { ERK1/2 } \uparrow \\
\text { p38, JNK } \downarrow\end{array}$ & $\begin{array}{l}\text { renal } \\
\text { protection }\end{array}$ & {$[51]$} \\
\hline
\end{tabular}

the suppression of NF- $\kappa \mathrm{B}$ activation and concomitant inflammatory cytokine production through the inhibition of the ERK1/2 pathway. Another study showed that activation of the ERK1/2 pathway during I/R injury was linked to renal injury. When ERK1/2 inhibitor, U0126, was used to prevent ERK1/2 activation, there was a reduction in focal adhesion kinase, paxillin, and src phosphorylation. There was also increase in protection against focal adhesion restructuring and I/R-induced renal injury [62].

Taken together, most studies suggest ERK1/2 as a mediator of controlling cell survival in response to many stimuli including hypoxia/ischemia in the kidney. However, it is also reported that ERK1/2 is involved in injury and apoptosis rather than contributing to cell survival in kidney cells [61-63]. It is likely that ERK1/2 may have different effects on kidneys, which depends on experimental model, stress type, and many other factors. Therefore, ERK1/2 expression and phosphorylation, along with its renoprotective role need further clarification in future studies, especially among various models/species in different pathophysiological conditions.

\section{Other MAPKs}

Both p38 and JNK pathways are involved in pathological changes in human renal diseases, such as glomerulonephritis, diabetic nephropathy and acute renal failure. They can modulate the function of a variety of transcription factors through phosphorylation and thus induce a change in the pattern of gene transcription and results in inflammation and apoptosis [64]. In contrast, their inhibition might reduce I/R-induced apoptosis and inflammation and prevent cell death $[53,65]$. 
Hypoxia in combination with noradrenaline enhances the vasoreactivity of renal arteries after hypoxia/reoxygenation by activating p38 MAPK in mouse model, which was suggested to be essential for the pathogenesis of AKI [12]. Recent studies on rabbits in New Zealand showed that increasing the expression of aldehyde dehydrogenase 2 can reduce renal cell apoptosis by inhibiting the p38 and JNK pathways in rabbits with I/R injury [66]. Similar data indicated that p38 inhibition can significantly protect against renal I/R injury in a mouse I/R model [61]. NPC 31145, a specific p38 MAPK inhibitor, blocked the p38 pathway and prevented a loss of renal function and substantially reduced acute renal inflammation in the diseased rat and human kidney [65]. The results of some other studies also demonstrated that suppression of p38 and JNK consequently causes a significant decrease of cytochrome c release from the mitochondria, a fall in the ratios of both Bax/Bcl-2 and cleaved caspase-3/ caspase- 3 , and phosphorylation of p53. This ameliorated acute renal injury in both in mice model and in an in vitro culture model [28]. Glycyrrhizin also gives significant protection against I/R induced renal injury in mice by inhibiting inflammatory responses and renal cell apoptosis, associated with downregulation of p38 MAPK signaling [67]. Treatment of mouse proximal tubular epithelial cells with a p38 inhibitor, SB 203580, or a JNK inhibitor, SP600125, significantly suppressed LPS-induced chemokines CXCL2 and CCL2 mRNA expression [68]. Since CXCL2 expression in proximal renal tubular cells has been observed in ischemic renal injury, it suggests that $\mathrm{p} 38$ and JNK could be potential target molecules in the treatment of inflammatory injury.

Although the previous data predominantly showed that the inhibition of p38 and JNK reduces cell apoptosis, there are still other opinions about their role in hypoxic/ ischemic conditions. Recently, Lempiainen et al. [69] showed that dexmedetomidine, an $\alpha-2$ adrenoceptor agonist, upregulates p38 signaling, which ameliorated renal I/R injury and inflammatory responses in rat kidneys. Moreover, endotoxin exposure protects isolated kidney cells against hypoxia-induced cell death, which appears to be mediated in part via the p38 and JNK pathways [70]. A lipoxin receptor agonist, BML-111, inhibits renal I/R injury via activation of the $\mathrm{p} 38$ pathway in NRK-52E cells [71].

There are few studies of the role of ERK5 in renal I/R injury. Kawakami et al. [72] reported that over-expression of full length ERK5 in the kidney serves a protective role against I/R injury.

Based on current information, we are inclined to agree with the opinion that the activation of ERKs, including ERK1/2 and ERK5, is critical for cell survival, while p38 and JNK contribute to cell apoptosis during I/R injury. However, the precise roles of MAPKs in renal I/R injury are not straightforward and are influenced by many factors and signaling pathways such as p53 [59], PI3K/Akt signaling pathways [49, 73], as well as NF-kappaB signaling pathways [61]. Thus, the further investigation for the function of MAPK in renal I/R injury is necessary before finding a correct direction toward clinical targets for the treatment of renal injury.

\section{Chronic kidney diseases}

The primary cause of chronic kidney diseases (CKD) is often related, directly or indirectly, to hypoxic/ischemic injury. This includes blood hypoperfusion, hypoxia, inflammatory damage in the case of glomerulonephritis and pyelonephritis, and toxic damage, which ultimately results in renal dysfunction [74]. The progression of renal fibrosis involves activation of intrinsic kidney cells as well as infiltrated cells, which leads to excessive accumulation and deposition of extracellular matrix, and the eventual loss of kidney function [75]. Prolonged hypoxia/ischemia is one of the most general mechanisms of CKD and is the leading cause and progression factor of end-stage renal diseases. Indeed, it has been considered to be a significant microenvironmental factor in promoting renal tubular atrophy and interstitial fibrosis, which are hallmarks of chronic kidney diseases [76, 77]. 
Fibrosis is a process whereby functional tissue is replaced by connective tissue and is the end result of a complex cascade of cellular and molecular responses initiated by organ damage [78]. Once this phenomenon exceeds the level of physiological repair, it will result in loss of organ architecture as well as loss of functional tissue. Fibrosis presents a number of characteristic features, including inflammatory cell infiltration, an increase in interstitial fibroblasts and matrix, and tubular atrophy, which is linked to epithelial cell apoptosis and epithelial to mesenchymal transition (EMT). Another characteristic feature of progressive renal disease is a loss of post-glomerular peritubular capillaries which leads to a reduction in oxygen supply. Therefore, it has been widely proposed that hypoxia is one of the common pathways of chronic renal disease progression [7, 79].

The majority of in vitro studies with tubular epithelial cells show that hypoxia can induce pathological changes that are consistent with a fibrogenic phenotype, such as promoting ECM accumulation with a switch to production of interstitial collagen type I and suppressing matrix turnover [80, 81]. Hypoxia can induce miR-155 as a pro-fibrotic cytokine to regulate TGF- $\beta 1$ levels as well as the process of EMT; this promotes fibrosis of proximal tubule cells [82]. A transcription factor, Egr-1, is induced by hypoxia through the ERK1/2 pathway and can regulate the development of renal tubular EMT [83] In addition, hypoxia stimulates EMT of proximal tubular epithelial cells to a myofibroblastic phenotype [84, 85], a process that is increasingly implicated in fibrosis.

There is a range of organ-specific triggers during renal fibrosis; however, the fibrotic process and associated signaling pathways are highly conserved between different organs. MAPKs are involved in the pathology of a variety of kidney injuries, including renal fibrosis $[14,83]$. In vitro hypoxia promotes a fibrogenic phenotype [86] with increased proliferation, enhanced myofibroblast differentiation, and altered ECM metabolism, which are all changes that are associated with sustained activation of MAPK signaling pathways. MAPKs can promote the fibrotic response through a number of different mechanisms, including: production and activation of transforming growth factor- $\beta 1$ (TGF- $\beta 1$ ), regulation of TGF- $\beta 1$ Smad signaling; and TGF- $\beta 1$ independent pro-fibrotic actions; see review [16].

Shen et al. reported that pretreatment with metformin prevents renal fibrosis by preventing angiotensin II-induced ERK1/2 activation and ECM overproduction in angiotensin II-treated renal fibroblast NRK-49F cells [87]. Fluorofenidone treatment inhibits the progression of renal interstitial fibrosis by suppressing oxidative stress and ERK1/2 signaling pathways in rat proximal tubular epithelial cells [88]. Similarly, paclitaxel in low nontoxic doses also relieves the effects of renal fibrosis, by blocking many steps in the TGF$\beta 1$-induced signaling pathway, such as the ERK1/2 pathway in inner medullary collecting duct cells [89]. A newly developed angiotensin II receptor blocker, fimasartan, has beneficial effects in reducing renal oxidative stress, inflammation, and fibrosis by inhibition of the ERK1/2 and JNK pathways and upregulation of nuclear factor erythroid 2-related factor 2 signaling in mice with unilateral ureteral obstruction (UUO) and HK-2 cells [90]. Moreover, Kruppel-like factor 15 is a major factor in renal interstitial fibrosis, and can potentially prove to be an antifibrotic factor by regulating the ERK1/2 and JNK signaling pathways [91].

There is a study showing that p38 inhibition attenuates $\mathrm{H}_{2} \mathrm{O}_{2}$-induced apoptosis and alleviated renal tubulointerstitial fibrosis pathogenesis in tubular epithelial cells in rat and human kidneys [92]. NPC 31169, a specific p38 MAPK inhibitor, blocked the p38 pathway and inhibited renal fibrosis in rat unilateral ureteric obstruction model [93]. Wang et al. indicated that blocking p38 activity partially reduced interstitial fibrosis, tubular atrophy and interstitial inflammation in the stenotic kidney [94]. Reduction of tubulointerstitial fibrosis in unilateral ureteral obstruction mouse kidney and NRK-49F cells by spleen tyrosine kinase inhibition is associated with down-regulation of p38 MAPK, which can reduce deposition of ECM protein and the expression of smooth muscle proteins such as $\alpha$-smooth muscle actin, type I collagen, and fibronectin [95]. On the other hand, p38 activation of proximal tubular epithelial cells by astrocyte elevated gene- 1 plays an important role in TGF- $\beta 1$-induced epithelial to mesenchymal transition, which is an important cellular event in organogenesis, cancer and renal tubulointerstitial fibrosis [96]. A member of the MAPKKK family, apoptosis

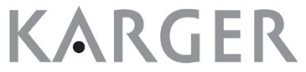




\begin{tabular}{|c|c|}
\hline Cellular Physiology & Cell Physiol Biochem 2016;39:1051-1067 \\
\hline and Biochemistry & $\begin{array}{l}\text { DOI: 10.1159/000447812 } \\
\text { Published online: August 22, } 2016\end{array}$ \\
\hline
\end{tabular}

Table 2. MAPKs versus renal fibrosis

\begin{tabular}{|c|c|c|c|}
\hline Stimuli/Conditions & $\begin{array}{l}\text { MAPK } \\
\text { Changes }\end{array}$ & Outcome & Reference \\
\hline peroxiredoxin 1 treatment in NRK-52E cells & p38 $\downarrow$ & $\begin{array}{l}\text { inhibit renal } \\
\text { fibrosis }\end{array}$ & {$[92]$} \\
\hline \multirow{2}{*}{$\begin{array}{l}\text { overexpression of astrocyte elevated gene- } 1 \text { in HK- } 2 \text { cells; } \\
\text { p38 inhibition in HK-2 cells }\end{array}$} & & promote EMT; & \multirow{2}{*}[96]{} \\
\hline & p38 $\downarrow$ & inhibit EMT & \\
\hline $\begin{array}{l}\text { SB203580 treatment in mouse renal artery stenosis } \\
\text { models and SB202190 treatment in rat MC cells }\end{array}$ & p38 $\downarrow$ & $\begin{array}{l}\text { reduce intertital } \\
\text { fibrosis }\end{array}$ & {$[94]$} \\
\hline $\begin{array}{l}\text { apoptosis signal-regulating kinase } 1 \text { deficient in mouse } \\
\text { kidneys }\end{array}$ & p38, JNK $\downarrow$ & $\begin{array}{l}\text { inhibit renal } \\
\text { fibrosis }\end{array}$ & {$[97]$} \\
\hline metformin pretreatment in mice and NRK- $49 \mathrm{~F}$ cells & 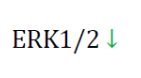 & $\begin{array}{l}\text { prevent renal } \\
\text { fibrosis }\end{array}$ & {$[87]$} \\
\hline $\begin{array}{l}\text { astragaloside IV treatment in HK-2 cells; } \\
\text { SB203580 treatment in HK-2 cells; } \\
\text { TGF-beta1 treatment in HK-2 cells }\end{array}$ & $\begin{array}{l}\text { p38, JNK } \downarrow \text {; } \\
\text { p38 } \\
\text { p38, JNK } \uparrow\end{array}$ & $\begin{array}{l}\text { inhibit fibrosis; } \\
\text { inhibit fibrosis; } \\
\text { promote fibrosis }\end{array}$ & {$[98]$} \\
\hline fimasartan treatment in mouse kidney and HK-2 cells & $\begin{array}{l}\text { ERK1/2, } \\
\text { JNK } \downarrow\end{array}$ & $\begin{array}{l}\text { inhibit renal } \\
\text { fibrosis }\end{array}$ & {$[90]$} \\
\hline $\begin{array}{l}\text { spleen tyrosine kinase inhibition in UUO mouse kidneys } \\
\text { and NRK-49F cells }\end{array}$ & p38 $\downarrow$ & $\begin{array}{l}\text { inhibit renal } \\
\text { fibrosis }\end{array}$ & {$[95]$} \\
\hline NPC 31169 treatment in rat UUO model & p38 $\downarrow$ & $\begin{array}{l}\text { inhibit renal } \\
\text { fibrosis }\end{array}$ & {$[93]$} \\
\hline $\begin{array}{l}\text { paclitaxel treatment in IMCD cells; } \\
\text { TGF-beta1 treatment in IMCD cells }\end{array}$ & $\begin{array}{l}\text { ERK1/2, } \\
\text { JNK } \downarrow \text {; } \\
\text { ERK1/2, } \\
\text { JNK } \uparrow\end{array}$ & $\begin{array}{l}\text { ameliorate } \\
\text { fibrosis; } \\
\text { promote fibrosis }\end{array}$ & [89] \\
\hline fluorofenidone treatment in NRK-52E cells & $\mathrm{ERK} 1 / 2 \downarrow$ & $\begin{array}{l}\text { inhibit renal } \\
\text { fibrosis }\end{array}$ & {$[88]$} \\
\hline $\begin{array}{l}\text { kruppel-like factor } 15 \text { in NRK- } 49 \mathrm{~F} \text { cells; } \\
\text { TGF-beta1 treatment in NRK-49F cells }\end{array}$ & $\begin{array}{l}\text { ERK1/2, } \\
\text { JNK } \downarrow ; \\
\text { ERK1/2, } \\
\text { JNK } \uparrow\end{array}$ & $\begin{array}{l}\text { inhibit fibrosis; } \\
\text { promote fibrosis }\end{array}$ & {$[91]$} \\
\hline
\end{tabular}

signal-regulating kinase 1, can induce activation of p38 and JNK to promote renal fibrosis in an obstructed mouse kidney [97]. Xu et al. showed that increasing the activation of the JNK and p38 pathways plays a prominent role in renal tubular cell apoptosis, which subsequently accelerates the progression of renal tubulointerstitial fibrosis. As such, the inhibitory effect of astragaloside IV on cell apoptosis may be related to the inhibition of these two MAPK signaling pathways [98]. Moreover, Baicalein protects against inflammatory responses in the unilateral ureteral obstruction mouse model to ameliorate tubulointerstitial fibrosis via inactivation of NF- $\mathrm{kB}$ and MAPK signal pathways [99].

All these studies suggest that MAPKs play important roles in the transformation process of the renal fibrosis. Activation of one or multiple MAPKs can have a potential effect on the signaling pathways in the development and progression of renal fibrosis. Suppressing ERK1/2 individually or with p38/JNK signaling can inhibit the progress of renal fibrosis. Therefore, a blockage of MAPKs may have therapeutic potential for the treatment of chronic renal fibrosis.

\section{Renal tumorigenesis}

Hypoxia is commonly associated with the pathological changes of many types of solid tumors, including renal tumors [100]. Tumor hypoxia and the critical molecular mediators of hypoxia, hypoxia-inducible factors (HIFs), regulate multiple steps of renal tumorigenesis including tumor formation, progression, and response to therapy [100, 101]. To date, 
three HIFs (HIF-1, -2, and -3) have been identified that regulate transcriptional programs in response to low oxygen levels. Consistent with tumor hypoxia as a mechanism of HIF activation, HIF proteins are commonly detected in perinecrotic regions of sporadic tumors and overlaps with staining for known hypoxic markers. A recent survey of malignant and normal tissues found that the expression of both HIF-1 and HIF-2 is commonly increased in a variety of human tumors, including bladder, breast, colon, glial, hepatocellular, ovarian, pancreatic, prostate, and renal tumors [102]. A variety of clinical and mechanistic data supports that HIF-1 $\alpha$ has an important role in promoting tumorigenesis in a clinically important and large subset of human renal carcinoma (see review [103] by Gudas et al.).

Renal tumors account for approximately $3 \%$ of all neoplasias, with renal cell carcinoma (RCC) being the most widespread malignant tumor in the adult kidney. The most common RCC is the clear cell carcinoma (ccRCC), which represents about 70\% of all RCCs. The ccRCC is associated with von Hippel-Lindau (VHL) disease, which is characterized by its relatively poor prognosis due to late presentation and resistance to various therapeutical manipulations $[104,105]$. In response to hypoxic stress, several survival pathways are activated in renal tumor cells to perform their essential biological processes in different ways in comparison to normal cells. In ccRCC, hypoxic stress causes reactive oxygen species (ROS) production, which can lead to enhanced MAPK cascade stimulation [106]. The understanding of the signaling pathways involved in renal tumorigenesis will hopefully provide insight leading to the optimization of specific therapies for renal tumors.

An in vitro study [107] showed that the suppression of MAPK pathways impaired human ccRCC cells' proliferation, clonogenicity, anoikis resistance, migration, and invasion capabilities. Phosphorylated ERK1/2 expression is significantly upregulated in renal clear cell carcinoma when compared to normal cells, in relation to the pathological grade and clinical stage of ccRCC [108]. Oka et al. described that constitutive activation of MAPKs may be associated with the carcinogenesis of human renal cell carcinoma [109]. Huang et al. in vivo studies showed that the expression of MAPK kinase 1 and ERK2 in human clear cell RCC were significantly higher than normal controls, and the suppression of one or more MAPK signaling pathways using Anthrax lethal toxin inhibited RCC growth by disrupting tumor vasculature [110].

MAPKs appear to be critical in the activation of the HIF-1. It was reported that either ERK1/2 or p38 can phosphorylate HIF-1 [111-113], while inhibition of these two MAPKs was capable of blocking the expression of reporter genes of the HIF-1 activity [114]. More recently, the use of p38 as a potential biomarker of ccRCC, which correlates well with Fuhrman grade, has been proposed [115]. In short, there is noticeable evidence suggesting that MAPK signaling pathways may be critical in the biological effects of the HIF in ccRCC and that the activation of MAPK signaling pathways plays a crucial role in tumorigenesis, metastasis, and angiogenesis of RCC. All this data suggests that MAPKs are linked to the progression of renal cell carcinomas.

ERK1/2

ERK1/2 has been thought as an important factor contributing to renal tumor proliferation since most studies show that ERK1/2 is critical for cell survival against stress. Suzuki et al. indicated that inhibiting the ERK1/2 pathway using bisebromoamide in ccRCC cell lines can induce apoptosis to combat tumor cell proliferation [116]. Also, stimulating alkaline phosphatase in renal tumor cell lines can deactivate ERK1/2; so, alkaline phosphatase may be used as a potential therapeutic target of RCC [117]. Docetaxel may suppress proliferation of RCC cells under in vitro and in vivo settings by suppressing cell growth, by inducing of both apoptosis and G2/M cell cycle arrest, which is related to reduced phosphorylation of ERK1/2 [118]. In vivo growth of a resistant to sunitinib human RCC cell line in nude mice is significantly inhibited after treatment with axitinib (compared to after treatment with sunitinib); accompanying the marked inhibition of angiogenesis, which proves that the antitumor activity of axitinib in RCC cells, at least in part, is involved in the inactivation of ERK1/2 [119]. RCC cell proliferation and invasion, as well as the inhibition of RCC cell apoptosis 
by activating the smad and ERK1/2 pathways can be mediated by nodal overexpression [120]. In RCC cells, simvastatin stimulates apoptosis, anti-metastasis, and the inhibition of the ERK1/2 pathway [121]. In addition, the effects of the multi-target drug, sorafenib, on ccRCC necrosis by regulating cyclophilin D expression are related to the inhibition of phosphorylated-ERK1/2 [122]. This data suggests that the ERK1/2 signaling pathway plays a vital role in renal carcinoma proliferation, with very few reports expressing an opposite opinion. Fang et al. suggested that the ERK1/2 signaling pathway mediates the regulation of cell cycle-related proteins, effectively inhibits cell proliferation, and also causes G1 phase arrest in RCC cell lines [123]. Protein kinase C epsilon ( $\mathrm{PKC} \varepsilon$ ) plays as an important mediator in cancer stem cell pathogenesis of renal cell cancer by regulating the phosphorylation of ERK1/2 in RCC 769P side population cell line [124]. Xu et al. suggested that the anti-tumor activities of acyldepsipeptides are dependent on the down-regulated expressions of cyclin D1, CDK4, and PCNA, along with the decreased expression of phosphorylated ERK1/2 in renal 786-0 and 769-P cells [125]. Restraining the activation of ERK1/2 suppressed cellular proliferation and migration in an RCC cell line (786-0), this suggested that ERK1/2 may play important roles as a positive regulator to RCC [126].

In short, ERK1/2 activation may contribute to renal tumor cell proliferation and metastasis.

p38 / JNK

The p38 and JNK pathways act as pro-apoptotic factors. It was reported that overproduction of ROS due to cisplatin administration in cancer patients can trigger inflammatory responses and apoptosis in rat kidneys by increasing the expression of proinflammatory cytokine, tumor necrosis factor- $\alpha$ and apoptotic marker p38 [127]. Kim et al. indicated that p38 mediates interleukin 4-induced growth inhibition and cellular senescence in certain human RCC cell lines [128]. Inhibition of the p38 MAPK and JNK signaling pathways attenuated mifepristone-induced apoptotic cell death and anti-tumor activity via regulating the expression of CCAAT/enhancer-binding protein homologous protein in renal carcinoma cells [129]. These studies showed above suggest that p38 MAPK and JNK signaling pathways may act as anti-tumor factors in renal carcinomas. Although, it is also showed that JNK activity affects pVHL-deficient RCCs in in vitro and in vivo growth, JNK stimulates c-Jun phosphorylation, activation, and dimerization with c-Fos. This forms a transcriptionally competent activator protein- 1 complex, which drives the transcription of the Twist gene and induces EMT, which is essential for renal tumor metastasis [130]

\section{ERK5}

The specific knockdown of ERK5 in pVHL-negative cell lines promotes a decrease in proliferation and migration, thus supporting the role of this MAPK in cellular transformation. Furthermore, high levels of ERK5 correlated with more aggressive and metastatic stages of human ccRCC, based off a short series of fresh samples of the disease [131]. Therefore ERK5, similar to ERK1/2, very likely promotes renal tumor proliferation and migration.

Altogether, the activation of ERKs (including ERK1/2 and ERK5) has been associated with renal cancer proliferation and migration, while p38 and JNK may contribute to growth inhibition and cellular senescence in renal tumors. Chaves Neto et al have more evidence to help the argument. They demonstrated that downregulation of the ERK1/2 pathway and activation of the p38 and JNK pathways have antitumor effects. This is done through the inhibition of matrix metalloproteinase- 2 activity and reducing the expression of renal cancer aggressiveness markers caveolin-1, low molecular weight phosphotyrosine protein phosphatase, as well as vascular endothelial growth factor receptor 2 [132]. Since there is substantial data on the role of MAPK-mediated signaling in controlling renal tumorigenesis, MAPK pathways may have great therapeutic value against ccRCC. However, it may be a complex issue to enhance or inhibit one or more MAPKs specifically, in renal cancer treatment since many factors affect the outcome. 


\section{Cellular Physiology Cell Physiol Biochem 2016;39:1051-1067

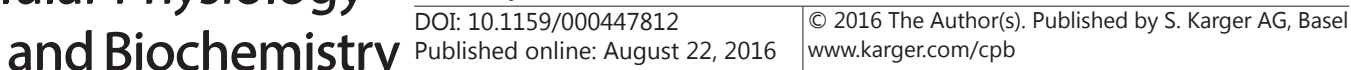 \\ Luo et al.: MAP Kinases and Renal Hypoxia/Ischemia}

\section{Conclusions}

Renal hypoxia/ischemia is a common condition in clinical settings and is associated with many disorders. Among the complex mechanisms underlying hypoxic/ischemic pathophysiology in the kidney, MAPK signaling is critically involved in the genesis and progression of both acute and chronic kidney diseases as well as renal carcinoma. Activation of ERK1/2 or deactivation of p38/JNK may promote renal survival against I/R stress, while the same treatment may contribute to tumor cell proliferation and metastasis. It is therefore possible to prevent/treat hypoxic/ischemic kidney injury and other kidney diseases by targeting MAPK signals. However, more investigations are needed to further verify the clinical and laboratory results and elucidate the molecular mechanisms in detail. It is our belief that future studies will provide novel treatments of hypoxic/ischemic kidney disease by targeting MAPK pathways.

\section{Acknowledgments}

This work was supported by the National Natural Science Foundation of China (Grant No. 81273267), Memorial Hermann's Foundation and Vivian L Smith Neurologic Foundation.

\section{Disclosure Statement}

The authors declare no conflict of interest.

\section{References}

1 Segal SS: Regulation of blood flow in the microcirculation. Microcirculation 2005;12:33-45.

2 Singh P, Ricksten SE, Bragadottir G, Redfors B, Nordquist L: Renal oxygenation and haemodynamics in acute kidney injury and chronic kidney disease. Clin Exp Pharmacol Physiol 2013;40:138-147.

3 Blantz RC, Deng A, Miracle CM, Thomson SC: Regulation of kidney function and metabolism: a question of supply and demand. Trans Am Clin Climatol Assoc 2007;118:23-43.

4 Fine LG, Bandyopadhay D, Norman JT: Is there a common mechanism for the progression of different types of renal diseases other than proteinuria? Towards the unifying theme of chronic hypoxia. Kidney Int 2000;75:S22-26.

5 Bonomini M, Del Vecchio L, Sirolli V, Locatelli F: New Treatment Approaches for the Anemia of CKD. Am J Kidney Dis 2015;10.1053/j.ajkd.2015.06.030

6 Louis K, Hertig A: How tubular epithelial cells dictate the rate of renal fibrogenesis? World J Nephrol 2015;4:367-373.

7 Eckardt KU, Bernhardt WM, Weidemann A, Warnecke C, Rosenberger C, Wiesener MS, Willam C: Role of hypoxia in the pathogenesis of renal disease. Kidney Int 2005;10.1111/j.1523-1755.2005.09909.xS46-51.

8 Haase VH: Mechanisms of hypoxia responses in renal tissue. J Am Soc Nephrol 2013;24:537-541.

9 Feng Y, Liu Y, Wang L, Cai X, Wang D, Wu K, Chen H, Li J, Lei W: Sustained oxidative stress causes late acute renal failure via duplex regulation on p38 MAPK and Akt phosphorylation in severely burned rats. PLoS One 2013;8:e54593.

10 Potthoff SA, Fahling M, Clasen T, Mende S, Ishak B, Suvorava T, Stamer S, Thieme M, Sivritas SH, Kojda G, Patzak A, Rump LC, Stegbauer J: Angiotensin-(1-7) modulates renal vascular resistance through inhibition of p38 mitogen-activated protein kinase in apolipoprotein E-deficient mice. Hypertension 2014;63:265-272.

11 Aguilar-Alonso FA, Solano JD, Vargas-Olvera CY, Pacheco-Bernal I, Pariente-Perez TO, Ibarra-Rubio ME: MAPKs' status at early stages of renal carcinogenesis and tumors induced by ferric nitrilotriacetate. Mol Cell Biochem 2015;404:161-170. 
12 Kaufmann J, Martinka P, Moede O, Sendeski M, Steege A, Fahling M, Hultstrom M, Gaestel M, Moraes-Silva IC, Nikitina T, Liu ZZ, Zavaritskaya O, Patzak A: Noradrenaline enhances angiotensin II responses via p38 MAPK activation after hypoxia/re-oxygenation in renal interlobar arteries. Acta Physiol (Oxf) 2015;213:920-932.

13 Liu WH, Liu HB, Gao DK, Ge GQ Zhang P, Sun SR, Wang HM, Liu SB: ABCG2 protects kidney side population cells from hypoxia/reoxygenation injury through activation of the MEK/ERK pathway. Cell Transplant 2013;22:1859-1868.

14 Kyriakis JM, Avruch J: Mammalian mitogen-activated protein kinase signal transduction pathways activated by stress and inflammation. Physiol Rev 2001;81:807-869.

15 Kyriakis JM, Avruch J: Mammalian MAPK signal transduction pathways activated by stress and inflammation: a 10-year update. Physiol Rev 2012;92:689-737.

16 Ma FY, Sachchithananthan M, Flanc RS, Nikolic-Paterson DJ: Mitogen activated protein kinases in renal fibrosis. Front Biosci (Schol Ed) 2009;1:171-187.

17 Gan X, Huang S, Wu L, Wang Y, Hu G, Li G, Zhang H, Yu H, Swerdlow RH, Chen JX, Yan SS: Inhibition of ERKDLP1 signaling and mitochondrial division alleviates mitochondrial dysfunction in Alzheimer's disease cybrid cell. Biochim Biophys Acta 2014;1842:220-231.

18 Meng ZX, Wang L, Xiao Y, Lin JD: The Baf60c/Deptor pathway links skeletal muscle inflammation to glucose homeostasis in obesity. Diabetes 2014;63:1533-1545.

19 Kim EK, Choi EJ: Compromised MAPK signaling in human diseases: an update. Arch Toxicol 2015;89:867882.

20 Yang M, Huang CZ: Mitogen-activated protein kinase signaling pathway and invasion and metastasis of gastric cancer. World J Gastroenterol 2015;21:11673-11679.

21 Lewis TS, Shapiro PS, Ahn NG: Signal transduction through MAP kinase cascades. Adv Cancer Res 1998;74:49-139.

22 Son Y, Kim S, Chung HT, Pae HO: Reactive oxygen species in the activation of MAP kinases. Methods Enzymol 2013;528:27-48.

23 Soares-Silva M, Diniz FF, Gomes GN, Bahia D: The Mitogen-Activated Protein Kinase (MAPK) Pathway: Role in Immune Evasion by Trypanosomatids. Front Microbiol 2016;7:183.

24 Cassidy H, Radford R, Slyne J, O'Connell S, Slattery C, Ryan MP, McMorrow T: The role of MAPK in druginduced kidney injury. J Signal Transduct 2012;2012:463617.

25 Jha SK, Jha NK, Kar R, Ambasta RK, Kumar P: p38 MAPK and PI3K/AKT Signalling Cascades inParkinson's Disease. Int J Mol Cell Med 2015;4:67-86.

26 Ma MC, Qian H, Ghassemi F, Zhao P, Xia Y: Oxygen-sensitive \{delta\}-opioid receptor-regulated survival and death signals: novel insights into neuronal preconditioning and protection. J Biol Chem 2005;280:1620816218.

27 Omori S, Hida M, Ishikura K, Kuramochi S, Awazu M: Expression of mitogen-activated protein kinase family in rat renal development. Kidney Int 2000;58:27-37.

28 Chen J, Wang W, Zhang Q Li F, Lei T, Luo D, Zhou H, Yang B: Low molecular weight fucoidan against renal ischemia-reperfusion injury via inhibition of the MAPK signaling pathway. PLoS One 2013;8:e56224.

29 Chang NJ, Weng WH, Chang KH, Liu EK, Chuang CK, Luo CC, Lin CH, Wei FC, Pang ST: Genome-wide gene expression profiling of ischemia-reperfusion injury in rat kidney, intestine and skeletal muscle implicate a common involvement of MAPK signaling pathway. Mol Med Rep 2015;11:3786-3793.

30 Bokemeyer D, Guglielmi KE, McGinty A, Sorokin A, Lianos EA, Dunn MJ: Activation of extracellular signalregulated kinase in proliferative glomerulonephritis in rats. J Clin Invest 1997;100:582-588.

31 Sirintrapun SJ, Geisinger KR, Cimic A, Snow A, Hagenkord J, Monzon F, Legendre BL Jr, Ghazalpour A, Bender RP, Gatalica Z: Oncocytoma-like renal tumor with transformation toward high-grade oncocytic carcinoma: a unique case with morphologic, immunohistochemical, and genomic characterization. Medicine (Baltimore) 2014;93:e81.

32 Ahad A, Ahsan H, Mujeeb M, Siddiqui WA: Gallic acid ameliorates renal functions by inhibiting the activation of p38 MAPK in experimentally induced type 2 diabetic rats and cultured rat proximal tubular epithelial cells. Chem Biol Interact 2015;240:292-303.

33 Masaki T, Stambe C, Hill PA, Dowling J, Atkins RC, Nikolic-Paterson DJ: Activation of the extracellular-signal regulated protein kinase pathway in human glomerulopathies. J Am Soc Nephrol 2004;15:1835-1843.

34 Jiao Z, Chen J, Liu Y, Liu T, Chen K, Li G: Role of ERK1/2 and JNK phosphorylation in iodine contrast agentinduced apoptosis in diabetic rat kidneys. Ren Fail 2015;37:1349-1355. 


\section{Cellular Physiology Cell Physiol Biochem 2016;39:1051-1067 \begin{tabular}{l|l|l}
\hline DOI: 10.1159/000447812 & $\begin{array}{l}\text { C } 2016 \text { The Author(s). Published by S. Karger AG, Basel } \\
\text { www.karger.com/cpb }\end{array}$ \\
\hline
\end{tabular}}

Luo et al.: MAP Kinases and Renal Hypoxia/Ischemia

35 Brady HR, Singer GG: Acute renal failure. Lancet 1995;346:1533-1540.

36 Charbonney E, Saudan P, Triverio PA, Quinn K, Mentha G, Martin PY: Prognosis of acute kidney injury requiring renal replacement therapy in solid organ transplanted patients. Transpl Int 2009;22:1058-1063.

37 Dennen P, Douglas IS, Anderson R: Acute kidney injury in the intensive care unit: an update and primer for the intensivist. Crit Care Med 2010;38:261-275.

38 Li Y, Zhong D, Lei L, Jia Y, Zhou H, Yang B: Propofol Prevents Renal Ischemia-Reperfusion Injury via Inhibiting the Oxidative Stress Pathways. Cell Physiol Biochem 2015;37:14-26.

39 Menke J, Sollinger D, Schamberger B, Heemann U, Lutz J: The effect of ischemia/reperfusion on the kidney graft. Curr Opin Organ Transplant 2014;19:395-400.

40 Legrand M, Mik EG, Johannes T, Payen D, Ince C: Renal hypoxia and dysoxia after reperfusion of the ischemic kidney. Mol Med 2008;14:502-516.

41 Yu W, Beaudry S, Negoro H, Boucher I, Tran M, Kong T, Denker BM: H2O2 activates G protein, alpha 12 to disrupt the junctional complex and enhance ischemia reperfusion injury. Proc Natl Acad Sci USA 2012;109:6680-6685.

42 Preising C, Schneider R, Bucher M, Gekle M, Sauvant C: Regulation of Expression of Renal Organic Anion Transporters OAT1 and OAT3 in a Model of Ischemia/Reperfusion Injury. Cell Physiol Biochem 2015;37:113.

43 Guan X, Qian Y, Shen Y, Zhang L, Du Y, Dai H, Qian J, Yan Y: Autophagy protects renal tubular cells against ischemia / reperfusion injury in a time-dependent manner. Cell Physiol Biochem 2015;36:285-298.

44 Cross TG, Scheel-Toellner D, Henriquez NV, Deacon E, Salmon M, Lord JM: Serine/threonine protein kinases and apoptosis. Exp Cell Res 2000;256:34-41.

45 Pearson G, Robinson F, Beers Gibson T, Xu BE, Karandikar M, Berman K, Cobb MH: Mitogen-activated protein (MAP) kinase pathways: regulation and physiological functions. Endocr Rev 2001;22:153-183.

46 di Mari JF, Davis R, Safirstein RL: MAPK activation determines renal epithelial cell survival during oxidative injury. Am J Physiol 1999;277:F195-203.

47 Park KM, Chen A, Bonventre JV: Prevention of kidney ischemia/reperfusion-induced functional injury and JNK, p38, and MAPK kinase activation by remote ischemic pretreatment. J Biol Chem 2001;276:1187011876.

48 Park KM, Kramers C, Vayssier-Taussat M, Chen A, Bonventre JV: Prevention of kidney ischemia/reperfusioninduced functional injury, MAPK and MAPK kinase activation, and inflammation by remote transient ureteral obstruction. J Biol Chem 2002;277:2040-2049.

49 Kwon DS, Kwon CH, Kim JH, Woo JS, Jung JS, Kim YK: Signal transduction of MEK/ERK and PI3K/Akt activation by hypoxia/reoxygenation in renal epithelial cells. Eur J Cell Biol 2006;85:1189-1199.

50 Kunduzova OR, Bianchi P, Pizzinat N, Escourrou G, Seguelas MH, Parini A, Cambon C: Regulation of JNK/ ERK activation, cell apoptosis, and tissue regeneration by monoamine oxidases after renal ischemiareperfusion. FASEB J 2002;16:1129-1131.

51 Yang CW, Ahn HJ, Jung JY, Kim WY, Li C, Choi BS, Kim HW, Kim YS, Moon IS, Kim J, Bang BK: Preconditioning with cyclosporine A or FK506 differentially regulates mitogen-activated protein kinase expression in rat kidneys with ischemia/reperfusion injury. Transplantation 2003;75:20-24.

52 Li C, Wang T, Zhang C, Xuan J, Su C, Wang Y: Quercetin attenuates cardiomyocyte apoptosis via inhibition of JNK and p38 mitogen-activated protein kinase signaling pathways. Gene 2016;577:275-280.

53 Hung CC, Ichimura T, Stevens JL, Bonventre JV: Protection of renal epithelial cells against oxidative injury by endoplasmic reticulum stress preconditioning is mediated by ERK1/2 activation. J Biol Chem 2003;278:29317-29326.

54 Chen HH, Lu PJ, Chen BR, Hsiao M, Ho WY, Tseng CJ: Heme oxygenase-1 ameliorates kidney ischemiareperfusion injury in mice through extracellular signal-regulated kinase 1/2-enhanced tubular epithelium proliferation. Biochim Biophys Acta 2015;1852:2195-2201.

55 Park KM, Fogelgren B, Zuo X, Kim J, Chung DC, Lipschutz JH: Exocyst Sec10 protects epithelial barrier integrity and enhances recovery following oxidative stress, by activation of the MAPK pathway. Am J Physiol Renal Physiol 2010;298:F818-826.

56 Fogelgren B, Zuo X, Buonato JM, Vasilyev A, Baek JI, Choi SY, Chacon-Heszele MF, Palmyre A, Polgar N, Drummond I, Park KM, Lazzara MJ, Lipschutz JH: Exocyst Sec10 protects renal tubule cells from injury by EGFR/MAPK activation and effects on endocytosis. Am J Physiol Renal Physiol 2014;307:F1334-1341. 


\section{Cellular Physiology Cell Physiol Biochem 2016;39:1051-1067

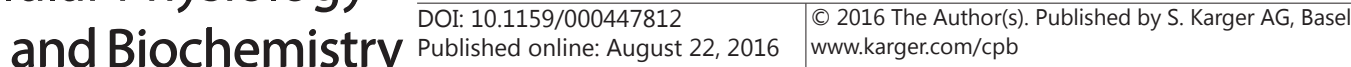 \\ Luo et al.: MAP Kinases and Renal Hypoxia/Ischemia}

57 Jang HS, Han SJ, Kim JI, Lee S, Lipschutz JH, Park KM: Activation of ERK accelerates repair of renal tubular epithelial cells, whereas it inhibits progression of fibrosis following ischemia/reperfusion injury. Biochim Biophys Acta 2013;1832:1998-2008.

58 Weng X, Wang M, Chen H, Chen Z, Liu X: Ischemic postconditioning inhibits apoptosis of renal cells following reperfusion: a novel in vitro model. Int Urol Nephrol 2015;47:1067-1074.

59 Zou YR, Zhang J, Wang J, Peng L, Li GS, Wang L: Erythropoietin Receptor Activation Protects the Kidney From Ischemia/Reperfusion-Induced Apoptosis by Activating ERK/p53 Signal Pathway. Transplant Proc 2016;48:217-221.

60 Choi DE, Jeong JY, Lim BJ, Na KR, Shin YT, Lee KW: Pretreatment with the tumor nerosis factor-alpha blocker etanercept attenuated ischemia-reperfusion renal injury. Transplant Proc 2009;41:3590-3596.

61 Ka SO, Hwang HP, Jang JH, Hyuk Bang I, Bae UJ, Yu HC, Cho BH, Park BH: The protein kinase 2 inhibitor tetrabromobenzotriazole protects against renal ischemia reperfusion injury. Sci Rep 2015;5:14816.

62 Alderliesten M, de Graauw M, Oldenampsen J, Qin Y, Pont C, van Buren L, van de Water B: Extracellular signal-regulated kinase activation during renal ischemia/reperfusion mediates focal adhesion dissolution and renal injury. Am J Pathol 2007;171:452-462.

63 Zhuang S, Schnellmann RG: A death-promoting role for extracellular signal-regulated kinase. J Pharmacol Exp Ther 2006;319:991-997.

64 Ma FY, Liu J, Nikolic-Paterson DJ: The role of stress-activated protein kinase signaling in renal pathophysiology. Braz J Med Biol Res 2009;42:29-37.

65 Stambe C, Atkins RC, Tesch GH, Kapoun AM, Hill PA, Schreiner GF, Nikolic-Paterson DJ: Blockade of p38alpha MAPK ameliorates acute inflammatory renal injury in rat anti-GBM glomerulonephritis. J Am Soc Nephrol 2003;14:338-351.

66 Zhong Z, Hu Q, Fu Z, Wang R, Xiong Y, Zhang Y, Liu Z, Wang Y, Ye Q: Increased Expression of Aldehyde Dehydrogenase 2 Reduces Renal Cell Apoptosis During Ischemia/Reperfusion Injury After Hypothermic Machine Perfusion. Artif Organs 2015;10.1111/aor.12607

67 Ye S, Zhu Y, Ming Y, She X, Liu H, Ye Q: Glycyrrhizin protects mice against renal ischemia-reperfusion injury through inhibition of apoptosis and inflammation by downregulating p38 mitogen-activated protein kinase signaling. Exp Ther Med 2014;7:1247-1252.

68 Jung YJ, Lee AS, Nguyen-Thanh T, Kim D, Kang KP, Lee S, Park SK, Kim W: SIRT2 Regulates LPS-Induced Renal Tubular CXCL2 and CCL2 Expression. J Am Soc Nephrol 2015;26:1549-1560.

69 Lempiainen J, Finckenberg P, Mervaala EE, Storvik M, Kaivola J, Lindstedt K, Levijoki J, Mervaala EM: Dexmedetomidine preconditioning ameliorates kidney ischemia-reperfusion injury. Pharmacol Res Perspect 2014;2:e00045.

70 Walshe CM, Laffey JG, Kevin L, O'Toole D: Sepsis protects the myocardium and other organs from subsequent ischaemic/reperfusion injury via a MAPK-dependent mechanism. Intensive Care Med Exp 2015;3:35.

71 Wu SH, Chen XQ, Lu J, Wang MJ: BML-111 Attenuates Renal Ischemia/Reperfusion Injury Via Peroxisome Proliferator-Activated Receptor-alpha-Regulated Heme Oxygenase-1. Inflammation 2015;10.1007/s10753015-0286-y

72 Kawakami T, Park SW, Kaku R, Yang J: Extracellular-regulated-kinase 5-mediated renal protection against ischemia-reperfusion injury. Biochem Biophys Res Commun 2012;418:603-608.

73 Nie H, Xue X, Li J, Liu X, Lv S, Guan G, Liu H, Liu G, Liu S, Chen Z: Nitro-oleic acid attenuates OGD/R-triggered apoptosis in renal tubular cells via inhibition of Bax mitochondrial translocation in a PPAR-gammadependent manner. Cell Physiol Biochem 2015;35:1201-1218.

74 Mutsaers HA, Stribos EG, Glorieux G, Vanholder R, Olinga P: Chronic Kidney Disease and Fibrosis: The Role of Uremic Retention Solutes. Front Med (Lausanne) 2015;2:60.

75 Li RX, Yiu WH, Tang SC: Role of bone morphogenetic protein-7 in renal fibrosis. Front Physiol 2015;6:114.

76 Fine LG, Norman JT: Chronic hypoxia as a mechanism of progression of chronic kidney diseases: from hypothesis to novel therapeutics. Kidney Int 2008;74:867-872.

77 Liu Y: Cellular and molecular mechanisms of renal fibrosis. Nat Rev Nephrol 2011;7:684-696.

78 Rockey DC, Bell PD, Hill JA: Fibrosis--a common pathway to organ injury and failure. N Engl J Med 2015;372:1138-1149.

79 Nangaku M: Chronic hypoxia and tubulointerstitial injury: a final common pathway to end-stage renal failure. J Am Soc Nephrol 2006;17:17-25. 


\section{Cellular Physiology Cell Physiol Biochem 2016;39:1051-1067

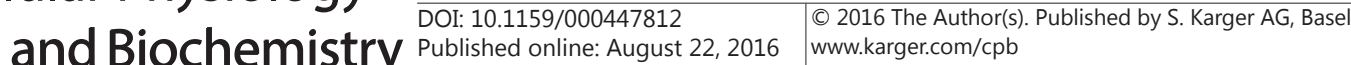 \\ Luo et al.: MAP Kinases and Renal Hypoxia/Ischemia}

80 Orphanides C, Fine LG, Norman JT: Hypoxia stimulates proximal tubular cell matrix production via a TGFbeta1-independent mechanism. Kidney Int 1997;52:637-647.

81 Li X, Kimura H, Hirota K, Kasuno K, Torii K, Okada T, Kurooka H, Yokota Y, Yoshida H: Synergistic effect of hypoxia and TNF-alpha on production of PAI-1 in human proximal renal tubular cells. Kidney Int 2005;68:569-583.

82 Xie S, Chen H, Li F, Wang S, Guo J: Hypoxia-induced microRNA-155 promotes fibrosis in proximal tubule cells. Mol Med Rep 2015;11:4555-4560.

83 Sun S, Ning X, Zhai Y, Du R, Lu Y, He L, Li R, Wu W, Sun W, Wang H: Egr-1 mediates chronic hypoxia-induced renal interstitial fibrosis via the PKC/ERK pathway. Am J Nephrol 2014;39:436-448.

84 Manotham K, Tanaka T, Matsumoto M, Ohse T, Inagi R, Miyata T, Kurokawa K, Fujita T, Ingelfinger JR, Nangaku M: Transdifferentiation of cultured tubular cells induced by hypoxia. Kidney Int 2004;65:871-880.

85 Du R, Xia L, Ning X, Liu L, Sun W, Huang C, Wang H, Sun S: Hypoxia-induced Bmi1 promotes renal tubular epithelial cell-mesenchymal transition and renal fibrosis via PI3K/Akt signal. Mol Biol Cell 2014;25:26502659.

86 Norman JT, Clark IM, Garcia PL: Hypoxia promotes fibrogenesis in human renal fibroblasts. Kidney Int 2000;58:2351-2366.

87 Shen Y, Miao N, Xu J, Gan X, Xu D, Zhou L, Xue H, Zhang W, Lu L: Metformin Prevents Renal Fibrosis in Mice with Unilateral Ureteral Obstruction and Inhibits Ang II-Induced ECM Production in Renal Fibroblasts. Int J Mol Sci 2016;17: pii: E146. doi: 10.3390/ijms17020146.

88 Qin J, Mei WJ, Xie YY, Huang L, Yuan QJ, Hu GY, Tao LJ, Peng ZZ: Fluorofenidone attenuates oxidative stress and renal fibrosis in obstructive nephropathy via blocking NOX2 (gp91phox) expression and inhibiting ERK/MAPK signaling pathway. Kidney Blood Press Res 2015;40:89-99.

89 Jung ES, Lee J, Heo NJ, Kim S, Kim DK, Joo KW, Han JS: Low-dose paclitaxel ameliorates renal fibrosis by suppressing transforming growth factor-beta1-induced plasminogen activator inhibitor-1 signaling. Nephrology (Carlton) 2016;10.1111/nep.12747

90 Kim S, Kim SJ, Yoon HE, Chung S, Choi BS, Park CW, Shin SJ: Fimasartan, a Novel Angiotensin-Receptor Blocker, Protects against Renal Inflammation and Fibrosis in Mice with Unilateral Ureteral Obstruction: the Possible Role of Nrf2. Int J Med Sci 2015;12:891-904.

91 Gao X, Wu G, Gu X, Fu L, Mei C: Kruppel-like factor 15 modulates renal interstitial fibrosis by ERK/MAPK and JNK/MAPK pathways regulation. Kidney Blood Press Res 2013;37:631-640.

92 Mei W, Peng Z, Lu M, Liu C, Deng Z, Xiao Y, Liu J, He Y, Yuan Q Yuan X, Tang D, Yang H, Tao L: Peroxiredoxin 1 inhibits the oxidative stress induced apoptosis in renal tubulointerstitial fibrosis. Nephrology (Carlton) 2015;20:832-842.

93 Stambe C, Atkins RC, Tesch GH, Masaki T, Schreiner GF, Nikolic-Paterson DJ: The role of p38alpha mitogenactivated protein kinase activation in renal fibrosis. J Am Soc Nephrol 2004;15:370-379.

94 Wang D, Warner GM, Yin P, Knudsen BE, Cheng J, Butters KA, Lien KR, Gray CE, Garovic VD, Lerman LO, Textor SC, Nath KA, Simari RD, Grande JP: Inhibition of p38 MAPK attenuates renal atrophy and fibrosis in a murine renal artery stenosis model. Am J Physiol Renal Physiol 2013;304:F938-947.

95 Chen KH, Hsu HH, Yang HY, Tian YC, Ko YC, Yang CW, Hung CC: Inhibition of spleen tyrosine kinase (syk) suppresses renal fibrosis through anti-inflammatory effects and down regulation of the MAPK-p38 pathway. Int J Biochem Cell Biol 2016;10.1016/j.biocel.2016.03.001

96 Wei J, Li Z, Chen W, Ma C, Zhan F, Wu W, Peng Y: AEG-1 participates in TGF-beta1-induced EMT through p38 MAPK activation. Cell Biol Int 2013;37:1016-1021.

97 Ma FY, Tesch GH, Nikolic-Paterson DJ: ASK1/p38 signaling in renal tubular epithelial cells promotes renal fibrosis in the mouse obstructed kidney. Am J Physiol Renal Physiol 2014;307:F1263-1273.

98 Xu W, Shao X, Tian L, Gu L, Zhang M, Wang Q, Wu B, Wang L, Yao J, Xu X, Mou S, Ni Z: Astragaloside IV ameliorates renal fibrosis via the inhibition of mitogen-activated protein kinases and antiapoptosis in vivo and in vitro. J Pharmacol Exp Ther 2014;350:552-562.

99 Wang W, Zhou PH, Xu CG, Zhou XJ, Hu W, Zhang J: Baicalein attenuates renal fibrosis by inhibiting inflammation via down-regulating NF-kappaB and MAPK signal pathways. J Mol Histol 2015;46:283-290.

100 Schodel J, Grampp S, Maher ER, Moch H, Ratcliffe PJ, Russo P, Mole DR: Hypoxia, Hypoxia-inducible Transcription Factors, and Renal Cancer. Eur Urol 2015;10.1016/j.eururo.2015.08.007

101 Masoud GN, Li W: HIF-1 pathway: role, regulation and intervention for cancer therapy. Acta Pharm Sin B 2015;5:378-389. 


\section{Cellular Physiology Cell Physiol Biochem 2016;39:1051-1067

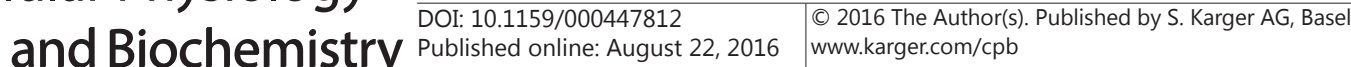 \\ Luo et al.: MAP Kinases and Renal Hypoxia/Ischemia}

102 Talks KL, Turley H, Gatter KC, Maxwell PH, Pugh CW, Ratcliffe PJ, Harris AL: The expression and distribution of the hypoxia-inducible factors HIF-1alpha and HIF-2alpha in normal human tissues, cancers, and tumor-associated macrophages. Am J Pathol 2000;157:411-421.

103 Gudas LJ, Fu L, Minton DR, Mongan NP, Nanus DM: The role of HIF1alpha in renal cell carcinoma tumorigenesis. J Mol Med (Berl) 2014;92:825-836.

104 Motzer RJ, Russo P: Systemic therapy for renal cell carcinoma. J Urol 2000;163:408-417.

105 Siegel RL, Miller KD, Jemal A: Cancer statistics, 2015. CA Cancer J Clin 2015;65:5-29.

106 Lee YH, Morrison BL, Bottaro DP: Synergistic signaling of tumor cell invasiveness by hepatocyte growth factor and hypoxia. J Biol Chem 2014;289:20448-20461.

107 Lee HW, Joo KM, Lim JE, Cho HJ, Cho HJ, Park MC, Seol HJ, Seo SI, Lee JI, Kim S, Jeong BC, Nam DH: Tpl2 kinase impacts tumor growth and metastasis of clear cell renal cell carcinoma. Mol Cancer Res 2013;11:1375-1386.

108 Chen Q, Lu HS, Gan MF, Chen LX, He K, Fan GM, Cao XQ: Expression and prognostic role of MEKK3 and pERK in patients with renal clear cell carcinoma. Asian Pac J Cancer Prev 2015;16:2495-2499.

109 Oka H, Chatani Y, Hoshino R, Ogawa O, Kakehi Y, Terachi T, Okada Y, Kawaichi M, Kohno M, Yoshida O: Constitutive activation of mitogen-activated protein (MAP) kinases in human renal cell carcinoma. Cancer Res 1995;55:4182-4187.

110 Huang D, Ding Y, Luo WM, Bender S, Qian CN, Kort E, Zhang ZF, VandenBeldt K, Duesbery NS, Resau JH, Teh BT: Inhibition of MAPK kinase signaling pathways suppressed renal cell carcinoma growth and angiogenesis in vivo. Cancer Res 2008;68:81-88.

111 Richard DE, Berra E, Gothie E, Roux D, Pouyssegur J: p42/p44 mitogen-activated protein kinases phosphorylate hypoxia-inducible factor 1alpha (HIF-1alpha) and enhance the transcriptional activity of HIF-1. J Biol Chem 1999;274:32631-32637.

112 Sodhi A, Montaner S, Patel V, Zohar M, Bais C, Mesri EA, Gutkind JS: The Kaposi's sarcoma-associated herpes virus G protein-coupled receptor up-regulates vascular endothelial growth factor expression and secretion through mitogen-activated protein kinase and p38 pathways acting on hypoxia-inducible factor 1alpha. Cancer Res 2000;60:4873-4880.

113 Sang N, Stiehl DP, Bohensky J, Leshchinsky I, Srinivas V, Caro J: MAPK signaling up-regulates the activity of hypoxia-inducible factors by its effects on p300. J Biol Chem 2003;278:14013-14019.

114 Hur E, Chang KY, Lee E, Lee SK, Park H: Mitogen-activated protein kinase kinase inhibitor PD98059 blocks the trans-activation but not the stabilization or DNA binding ability of hypoxia-inducible factor-1alpha. Mol Pharmacol 2001;59:1216-1224.

115 Samaras V, Tsopanomichalou M, Stamatelli A, Arnaoutoglou C, Samaras E, Arnaoutoglou M, Poulias H, Barbatis C: Is there any potential link among caspase-8, p-p38 MAPK and bcl-2 in clear cell renal cell carcinomas? A comparative immunohistochemical analysis with clinical connotations. Diagn Pathol 2009;4:7.

116 Suzuki K, Mizuno R, Suenaga K, Teruya T, Tanaka N, Kosaka T, Oya M: Bisebromoamide, an extract from Lyngbya species, induces apoptosis through ERK and mTOR inhibitions in renal cancer cells. Cancer Med 2013;2:32-39.

117 Sharma U, Pal D, Prasad R: A novel role of alkaline phosphatase in the ERK1/2 dephosphorylation in renal cell carcinoma cell lines: a new plausible therapeutic target. Biochimie 2014;107:406-409.

118 Han TD, Shang DH, Tian Y: Docetaxel enhances apoptosis and G2/M cell cycle arrest by suppressing mitogen-activated protein kinase signaling in human renal clear cell carcinoma. Genet Mol Res 2016;15:doi: 10.4238/gmr.15017321.

119 Miyazaki A, Miyake H, Fujisawa M: Molecular mechanism mediating cytotoxic activity of axitinib in sunitinib-resistant human renal cell carcinoma cells. Clin Transl Oncol 2015;10.1007/s12094-015-1457-x

120 Zhang Z, Jiang T, Li Q, Wang J, Yang D, Li X, Wang Q, Song X: Nodal activates smad and extracellular signalregulated kinases 1/2 pathways promoting renal cell carcinoma proliferation. Mol Med Rep 2015;12:587594.

121 Fang Z, Tang Y, Fang J, Zhou Z, Xing Z, Guo Z, Guo X, Wang W, Jiao W, Xu Z, Liu Z: Simvastatin inhibits renal cancer cell growth and metastasis via AKT/mTOR, ERK and JAK2/STAT3 pathway. PLoS One 2013;8:e62823.

122 Hu W, Yuan Q Liu XH, Zhu HC, Lv SQ Wang XH: Cyclophilin D-mediated apoptosis attributes to sorafenibinduced cytotoxicity in clear cell-renal cell carcinoma. Eur J Pharmacol 2015;749:142-150. 


\section{Cellular Physiology Cell Physiol Biochem 2016;39:1051-1067 \begin{tabular}{l|l|l} 
DOI: 10.1159/000447812 & and Biochemistry & $\begin{array}{l}\text { O 2016 The Author(s). Published by S. Karger AG, Basel } \\
\text { www.karger.com/cpb }\end{array}$
\end{tabular} \\ Luo et al.: MAP Kinases and Renal Hypoxia/Ischemia}

123 Fang J, Wang H, Xi W, Cheng G, Wang S, Su S, Zhang S, Deng Y, Song Z, Xu A, Liu B, Cao J, Wang Z: Downregulation of tNASP inhibits proliferation through regulating cell cycle-related proteins and inactive ERK/MAPK signal pathway in renal cell carcinoma cells. Tumour Biol 2015;36:5209-5214.

124 Huang B, Fu SJ, Fan WZ, Wang ZH, Chen ZB, Guo SJ, Chen JX, Qiu SP: PKCepsilon inhibits isolation and stemness of side population cells via the suppression of ABCB1 transporter and PI3K/Akt, MAPK/ERK signaling in renal cell carcinoma cell line 769P. Cancer Lett 2016;376:148-154.

125 Xu S, Guo P, Gao Y, Shi Q, He D, Gao Y, Zhang H: Acyldepsipeptides inhibit the growth of renal cancer cells through G1 phase cell cycle arrest. Biochem Biophys Res Commun 2013;438:468-472.

126 Cao Q, Chen M, Li Z, Huang W, Jin Y, Ye X, Tong M: High Novel Oncogene with Kinase-Domain (NOK) Gene Expression is Associated with the Progression of Renal Cell Carcinoma. Clin Lab 2016;62:179-186.

127 Hegazy MG, Emam MA: Ethanolic extract of Trigonella Foenum Graecum attenuates cisplatin-induced nephro- and hepatotoxicities in rats. Cell Mol Biol (Noisy-le-grand) 2015;61:81-87.

128 Kim HD, Yu SJ, Kim HS, Kim YJ, Choe JM, Park YG, Kim J, Sohn J: Interleukin-4 induces senescence in human renal carcinoma cell lines through STAT6 and p38 MAPK. J Biol Chem 2013;288:28743-28754.

129 Jang JH, Min KJ, Kim S, Park JW, Kwon TK: RU486 Induces Pro-Apoptotic Endoplasmic Reticulum Stress Through the Induction of CHOP Expression by Enhancing C/EBPdelta Expression in Human Renal Carcinoma Caki Cells. J Cell Biochem 2016;117:361-369.

130 An J, Liu H, Magyar CE, Guo Y, Veena MS, Srivatsan ES, Huang J, Rettig MB: Hyperactivated JNK is a therapeutic target in pVHL-deficient renal cell carcinoma. Cancer Res 2013;73:1374-1385.

131 Arias-Gonzalez L, Moreno-Gimeno I, del Campo AR, Serrano-Oviedo L, Valero ML, Esparis-Ogando A, de la Cruz-Morcillo MA, Melgar-Rojas P, Garcia-Cano J, Cimas FJ, Hidalgo MJ, Prado A, Callejas-Valera JL, Nam-Cha SH, Gimenez-Bachs JM, Salinas-Sanchez AS, Pandiella A, del Peso L, Sanchez-Prieto R: ERK5/ BMK1 is a novel target of the tumor suppressor VHL: implication in clear cell renal carcinoma. Neoplasia 2013;15:649-659.

132 Chaves Neto AH, Pelizzaro-Rocha KJ, Fernandes MN, Ferreira-Halder CV: Antitumor activity of irradiated riboflavin on human renal carcinoma cell line 786-0. Tumour Biol 2015;36:595-604. 